\title{
Production and Properties of Lipase from a Newly Isolated Chromobacterium $^{\dagger}$
}

\author{
Tsutomu Yamaguchi, Noriyuki Muroya, Masakazu Isobe* \\ and Mamoru SugIURA* \\ Research Laboratory, Toyo Jozo Co., Ltd., Ohito-cho, Shizuoka-ken
}

Received August 2, 1972

\begin{abstract}
Out of some 750 strains of microorganisms, a potent bacterium for lipase production was isolated from soil and was identified as Chromobacterium viscosum.

The bacterium accumulates lipase in culture fluid when grown aerobically at $26^{\circ} \mathrm{C}$ for 3 days in a medium composed of soluble starch, soy bean meal, lard and inorganic salts.

Chromobacterium lipase had an optimum pH of 7.0 for activity at $37^{\circ} \mathrm{C}$, and an optimal temperature of $65^{\circ} \mathrm{C}$ at pH 7.0 . The enzyme retained $80 \%$ of the activity when heated for $10 \mathrm{~min}$ at $70^{\circ} \mathrm{C}$. This lipase was capable of hydrolyzing a variety of natural fats and oils, and it was more active on lard and butter than on olive oil. The activity was stimulated by $\mathrm{Ca}^{2+}, \mathrm{Mg}^{2+}, \mathrm{Mn}^{2+}$ and inhibited by $\mathrm{Cu}^{2+}, \mathrm{Hg}^{2+}$ and $\mathrm{Sn}^{2+}$. It was not diminished but rather stimulated by a high concentration of bile-salts.
\end{abstract}

It has been hitherto reported that there are a large number of lipase-producing microorganisms belonging to genera Aspergillus, ${ }^{11}$ Rhizopus, ${ }^{2,3)}$ Mucor, ${ }^{4,5 !}$ Candida, ${ }^{6 \sim 8 !}$ Scleroti$n i a^{9}$ and some other yeasts or molds.

In bacteria, however, only a few species were reported to produce lipase, which are Pseudomonas, ${ }^{10}$ Staphylococcus, ${ }^{11}$ and others.

The lipase producing microorganisms have been selected by the procedure in which the lipase activities were assayed by hydrolyzing abilities on olive oil. It is necessary for medical and industrial uses to obtain a lipase which is capable of hydrolyzing both vegetable and animal fats. A screening for lipaseproducing microorganisms was carried out using lard-emulsion as substrate for the determination of lipase activities and a gram negative bacterium which was confirmed to belong to genus Chromobacterium was found in these experiments.

Although the enzyme is capable of hydrolyzing a variety of fats and oils, it is more active on lard and butter than on olive oil. This lipase is quite stable to heat and in wide

\footnotetext{
$\uparrow$ Studies on Bacterial Lipase, Part I.

* Tokyo College of Pharmacy, Sakuragi, Ueno, Taitoku, Tokyo.
}

$\mathrm{pH}$ range. The active $\mathrm{pH}$ and temperature ranges are extremely broad.

The present paper deals with the screening of various microorganisms for the production of lipase, the determination of the potent bacterium, Chromobacterium, and the properties of the bacterial lipase.

\section{MATERIALS AND METHODS}

Isolation of microorganisms. Test tubes containing $10 \mathrm{ml}$ portion of the culture medium (olive oil or lard $2 \%,\left(\mathrm{NH}_{4}\right)_{2} \mathrm{SO}_{4} 0.5 \%, \mathrm{~K}_{2} \mathrm{HPO}_{4} 0.05 \%, \mathrm{MgSO}_{4}$. $7 \mathrm{H}_{2} \mathrm{O} \quad 0.025 \%, \mathrm{CaCO}_{3} 0.5 \%$ ) were inoculated with one $\mathrm{g}$ of soil or manure sample collected from various places and incubated at $30^{\circ} \mathrm{C}$ for $72 \mathrm{hr}$. A portion of each vigorously grown culture was transferred to fresh medium and cultured again under the same conditions. After the culture for the enrichment had been repeated three times, the grown organisms were isolated on the plates with above medium containing $2 \%$ agar. Thus, 750 strains were obtained in pure culture. Screening tests on the above strains, then, were made regarding lipase activity by the methods described below.

\section{Determination of lipase activity}

The assay was carried out in the following two methods.

1. Olive-PVA method (Olive oil emulsion system). This is a modified method of Yamada et al. ${ }^{12}$ The 
reaction mixture, composed of $5 \mathrm{ml}$ of olive oil-polyvinyl alcohol emulsion, $2 \mathrm{ml}$ of $0.1 \mathrm{M}$ phosphate buffer (pH 7.0) and $1 \mathrm{ml}$ of enzyme solution, was incubated at $37^{\circ} \mathrm{C}$ for $20 \mathrm{~min}$. Enzyme reaction was terminated with the addition of $15 \mathrm{ml}$ of acetone-ethanol mixture (1:1). Free fatty acid liberated was titrated with $0.05 \mathrm{~N} \mathrm{NaOH}$ and the titration value with boiled enzyme solution was subtracted. One unit of lipase is defined as the amount which liberates 1 mole of fatty acid per minute at $37^{\circ} \mathrm{C}$ at $\mathrm{pH} 7.0$. Polyvinyl alcohol (PVA) was the product of Wako Pure Chemicals Co. Olive oil (Japan pharmacopoeia) was the product of Tsukishima Yakuhin Co.

2. Lard-Tween 60 method (Lard emulsion system). In a homogenizer, $20 \mathrm{ml}$ of Tween $60,20 \mathrm{~g}$ of lard and $60 \mathrm{ml}$ of dejonized water were blended at room temperature for $5 \mathrm{~min}$ at $11,000 \mathrm{rpm}$.

The components of the reaction mixture and the procedure were the same as those for olive oil-PVA method except that lard emulsion was used in place of olive oil emulsion.

Taxonomical studies. Cells grown on nutrient agar at $30^{\circ} \mathrm{C}$ were employed for the morphological observations. Cultural characteristics were observed on the cultures grown at $30^{\circ} \mathrm{C}$ for $48 \mathrm{hr}$. Utilization of carbon sources was determined by the cultures on peptone medium containing $1.0 \%$ of various carbon sources.

Preparation of the lipase. Chromobacterium viscosum B-17 which was obtained from soil was cultured in $100 \mathrm{ml}$ of medium in $500 \mathrm{ml}$ Erlenmeyer flask on a rotary shaker at $26^{\circ} \mathrm{C}$ for about $50 \mathrm{hr}$. The medium used for the production of lipase was "B-medium" shown in Table I.

Table I. Chemical Composition of Media Used FOR THE SCREENING OF LIPASE-PRODUCING MICROORGANISMS

Microorganisms were aerobically grown in $50 \mathrm{ml}$ of medium in $500 \mathrm{ml}$ Erlenmeyer flask at $26^{\circ} \mathrm{C}$.

\begin{tabular}{|c|c|c|}
\hline & \multicolumn{2}{|c|}{ Medium } \\
\hline & A & B \\
\hline Soluble starch & $2.0 \%$ & $2.0 \%$ \\
\hline Soybean meal & 2.0 & 2.0 \\
\hline Olive oil ${ }^{a}$ & 1.0 & - \\
\hline $\operatorname{Lard}^{b}$ & - & 1.0 \\
\hline $\mathrm{K}_{2} \mathrm{HPO}_{4}$ & 0.2 & 0.2 \\
\hline Urea & 0.1 & 0.1 \\
\hline $\mathrm{MgSO}_{4} \cdot 7 \mathrm{H}_{2} \mathrm{O}$ & 0.1 & 0.1 \\
\hline $\mathrm{CaCO}_{3}$ & 0.5 & 0.5 \\
\hline $\mathrm{pH}$ & 7.0 & 7.0 \\
\hline
\end{tabular}

a) Japanese pharmaceutical grade.

b) Commercial preparation for industrial use.
The supernatant fluid of the culture was concentrated to about one third of the volume in vacuum at $30^{\circ} \mathrm{C}$. The concentrate was cooled and added cold ethanol to give the concentration of $50 \%(\mathrm{v} / \mathrm{v})$. The mixture was allowed to stand overnight in the cold and the resulting precipitate was removed by centrifugation. Cold ethanol was added to the supernatant to give an alcohol concentration of $80 \%(\mathrm{v} / \mathrm{v})$, and allowed to stand overnight in the cold. The precipitate thus formed was separated by centrifugation, washed twice with absolute ethanol and dried in vacuum. This powder was used as crude enzyme preparation.

\section{RESULTS AND DISCUSSION}

\section{Screening test}

About 250 strains of molds and yeasts and 500 strains of bacteria were isolated from soil by the procedure mentioned above. These microorganisms were inoculated into $10 \mathrm{ml}$ of the same medium used for the isolation. The cultivation was carried out on a reciprocal shaker at $26^{\circ} \mathrm{C}$ for 3 or 5 days. The cultured broth was centrifuged and lipase activity of the supernatant fluid was determined.

From the results of these experiments, 26 strains of molds and 24 strains of bacteria which show high lipolytic activities were selected.

In the above experiments lipase activities were assayed by hydrolyzing abilities of olive oil.

In order to obtain the lipase which is capable of hydrolyzing both vegetable and animal fats, these selected microorganisms were cultured in "B-medium" which contains lard instead of olive oil (Table I). Fifty $\mathrm{ml}$ each of the medium in $500 \mathrm{ml}$ flask were inoculated with $2 \mathrm{ml}$ of seed culture grown in the same medium for $24 \mathrm{hr}$, and were incubated in the same conditions as in the previous experiments.

The lipase activities were determined by the lard emulsion system, in which lard was used as substrate.

In these experiments, three bacterial strains showed high lipolytic activities in the culture fluid. Strain B-17 possessed particularly high potency of lipase. On the other hand, all the tested strains of molds showed no appreciable activities in these conditions. 
Identification of the strain $B-17$

Taxonomical studies of the strain B-17 were carried out according to references. ${ }^{13 \sim 15}$

The morphological and physiological properties of the strain B-17 are shown in Table II and Fig. 1.

These results indicate that this test organism may belong to the genus Chromobacterium.
By a comparison between the taxonomical properties of this Chromobacterium and the cultures belonging to the genus Chromobacterium obtained from the American Type Culture Collection, the strain B-17 appears to be most closely related to Chromobacterium viscostum ATCC 6918 except few differences on sugar utilization. Since these two strains did

Table II. Characteristics of the Strain B-17

Morphological Characteristics

Rod, 0.6 to 1.2 by 1.0 to 1.5 microns with rounded ends, occurring singly and in pairs.

Gram-negative. Motile with single polar flagellum.

Cultural Characteristics

(1) Nutrient agar colony: Circular, smooth, convex, entire, glistening, lustrous and viscous, yellowish-brown.

(2) Nutrient agar slant: Thick, moist, rugose, yellowish white growth, becoming purple.

(3) Potato agar slant: Abundant growth, glistening, violet.

(4) Gelatin stab: Heavy, purple pellicle, liquefied.

(5) Nutrient broth: Very turbid, white pellicle, broth turns brown.

Physiological Characteristics

(1) $\mathrm{pH}$ : Optimum 6.5 to 7.5 , range 5.5 to 9.0 .

(2) Temperature: Optimum $26^{\circ} \mathrm{C}$, range 5 to $37^{\circ} \mathrm{C}$.

(3) Aerobic.

(4) Oxidase negative

(5) Litmus milk: Acid formation.

(6) Milk: No peptonization, no coagulation.

(7) Indol not produced.

(8) Starch not hydrolyzed.

(9) Acetyl methyl carbinol not produced.

(10) Catalase positive.

(11) Nitrites produced from nitrates.

(12) Methyl red test: Negative.

(13) Ammonia not produced.

(14) Hydrogen sulfate not produced.

(15) Casein: Liquefaction.

(16) O-F test: Oxidation.

(17) Litmus reduced.

(18) Methylene blue not reduced.

(19) Citrate utilized.

(20) Ammonium salts and urea utilized.

(21) Production of acid from carbohydrate.

(a) Acid from arabinose, glucose, mannose, fructose, sucrose, trehalose.

(b) No acid from xylose, lactose, maltose, raffinose, sorbitol, inositol, glycerol, salicin, inulin, dextrin, starch, cellulose.

(c) No gas was produced from any of the above cited carbohydrates in peptone medium.

(22) Gluconate not produced.

(23) Arginine dihydrolase negative.

(24) Source: Soil. 


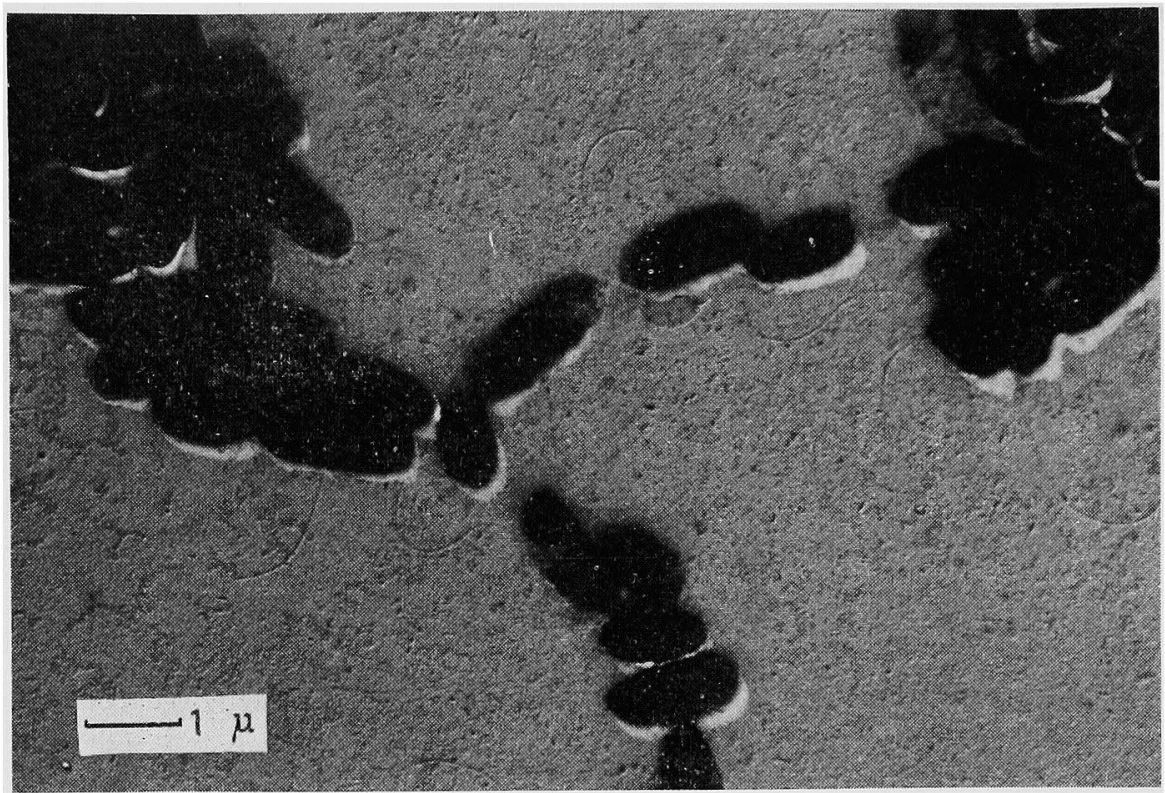

FIG. 1. Electron Micrograph of Strain B-17 (magnification, $\times 50,000$ ).

Table III Lipase Producibility of Various Bacteria Belonging to Genus Chromobacterium

Lipolytic activities represent the maximum values of the culture fluids during the cultivation. Cultural conditions are the same as in Table I.

\begin{tabular}{lccc}
\hline & $\begin{array}{c}\text { Incubation } \\
\text { time }(\mathrm{hr})\end{array}$ & $\begin{array}{c}\mathrm{pH} \\
\text { (final) }\end{array}$ & $\begin{array}{c}\text { Lipolytic } \\
\text { activity }(\mu / \mathrm{ml})\end{array}$ \\
\hline Chromobacterium viscosum B-17 & 70 & 6.2 & 38.55 \\
Chromobacterium viscosum ATCC 6918 & 56 & 6.2 & 5.83 \\
Chromobacterium violaceum ATCC 12472 & 96 & 6.8 & 3.45 \\
Chromobacterium amethystinum ATCC 6915 & 70 & 6.6 & 0.90 \\
Chromobacterium lividum ATCC 12473 & 70 & 6.6 & 0.75 \\
\hline
\end{tabular}

not differ greatly, it would be appropriate to conclude that the test organism is Chromobacterium viscosum $\mathrm{B}-17$.

Table III shows lipase productivity of the cultures belonging to genus Chromobacterium.

Chromobacterium viscosum $\mathrm{B}-17$ shows the highest lipase activity among the tested strains of genus Chromobacterium.

It has also been found that Chromobacterium viscosum ATCC 6918 and Chromobacterium violaceum ATCC 12472 produce lipase under the conditions of this experiment.

Some properties of crude enzymie preparation

Optimum $p H$ for lipase activity. The activity of Chromobacterium lipase at various
$\mathrm{pH}$ levels was assayed at $37^{\circ} \mathrm{C}$. The results are shown in Fig. 2.

The enzyme showed optimal activity between $\mathrm{pH} 7.0$ and 8.0, which coincides with the optimum for pancreatic ${ }^{16)}$ and milk lipase. ${ }^{17)}$ However, the enzyme was active over a wide range (3.0 to 11.0 ), especially on the acidic $\mathrm{pH}$. The property, that is active on the acid side, is a characteristic of this enzyme unlike the other bacterial lipases, such as Pseudomonas, ${ }^{10)}$ Micrococcus ${ }^{10)}$ and Staphylocorcus lipase ${ }^{11,18)}$

Optimal temperature for lipase activity. The optimal temperature for Chromobacterium lipase activity was determined at $\mathrm{pH} 7.0$ (Fig. 3). 


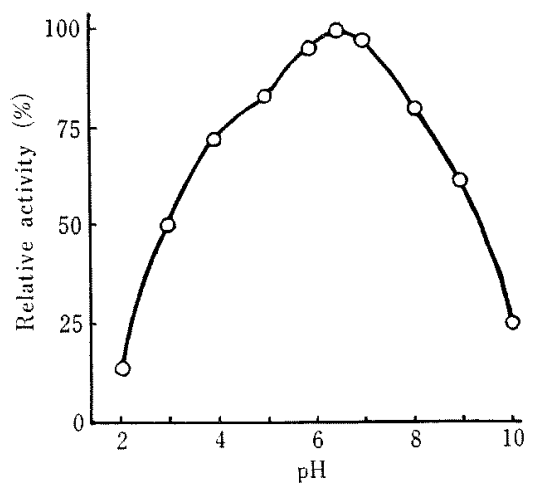

FIG. 2. Effect of $\mathrm{pH}$ on the Activity of Chromobacterium Lipase.

The $\mathrm{pH}$ values of the substrate were adjusted to 2.0 to 11.0 in half-unit intervals with the addition of $0.1 \mathrm{~N} \mathrm{HCl}$ or $\mathrm{NaOH}$. Two $\mathrm{ml}$ of $0.1 \mathrm{M} \mathrm{McIlvain}$ buffer of the same $\mathrm{pH}$ values and $1 \mathrm{ml}$ of enzyme solution were added to the substrate. After incubation at $37^{\circ} \mathrm{C}$ for $20 \mathrm{~min}$, the activity of the incubation mixture was assayed by the standard method.

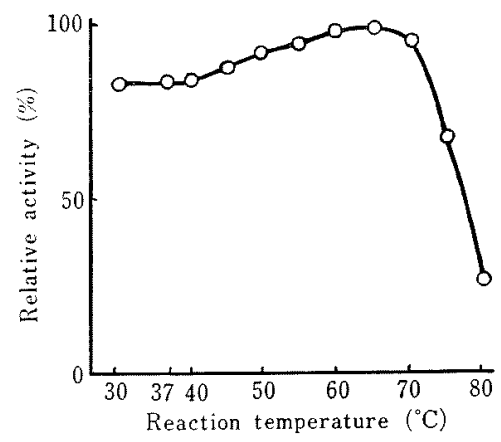

FIG. 3. Effect of Temperature on the Activity of Chromobacteruim Lipase

The enzyme reaction was carried out at $\mathrm{pH} 7.0$ for $20 \mathrm{~min}$ at various temperatures. The substrate was incubated at the test temperature before the enzyme solution was added.

The optimal temperature under the experimental conditions was $65^{\circ} \mathrm{C}$ with substantial activity between 30 and $70^{\circ} \mathrm{C}$ and little activity at $80^{\circ} \mathrm{C}$.

Thermal stability for the lipase activity. Figure 4 shows the lipolytic activity of the enzyme solution after exposure to various temperature at $\mathrm{pH} 7.0$.

In this figure, the lipolytic activity at $60^{\circ} \mathrm{C}$ is $10 \%$ higher than that at $30^{\circ} \mathrm{C}$. No proteinase

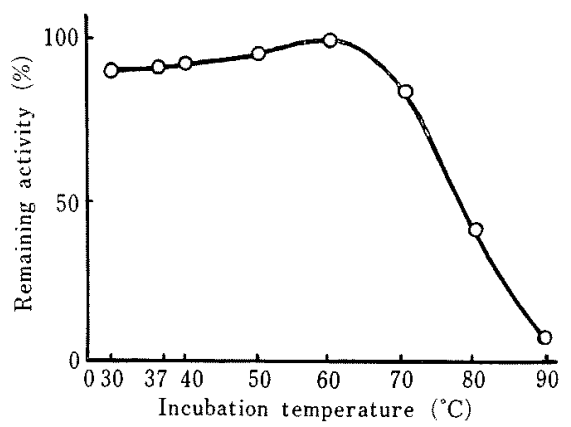

FIG. 4. Thermal Stability of Chromobacterium Lipase.

The enzyme solution was heated for 10 min at $\mathrm{pH} 7.0$ at various temperatures, then an aliquot $(1 \mathrm{ml})$ was withdrawn and immediately placed in prechilled tubes, and the remaining activities were assayed by the standard method.

activity was detected in this enzyme preparation when assayed using casein as substrate. It is not clear why the activity rises by the heat treatment. However, the enzyme lost $15,39,93$ and $97 \%$ of its activity when heated for $10 \mathrm{~min}$ at $70,80,90$ and $100^{\circ} \mathrm{C}$, respectively. These data show that this lipase is very stable to heat comparing with pancreatic, ${ }^{16)}$ micrococcal $^{10)}$ and staphylococcal ${ }^{18)}$ lipase.

$p H$-Stability for the lipase. The stability of the lipase in a solution of various $\mathrm{pH}$ values is shown in Fig. 5.

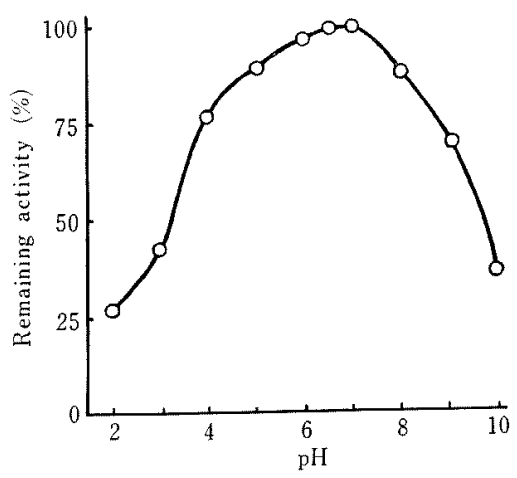

FIG. 5. Effect of $\mathrm{pH}$ on Stability of Chromobacterium Lipase.

The stock enzyme solution was diluted ten-fold with $5 \times 10^{-2} \mathrm{M}$ Mcllvain buffer of various $\mathrm{pH}$ values. After incubation at $37^{\circ} \mathrm{C}$ for $24 \mathrm{hr}$, aliquots were removed and the remaining activities were assayed by the standard method. 
The enzyme is quite stable over the range of $\mathrm{pH} 3.0$ to 9.0 on $24 \mathrm{hr}$ incubation at $37^{\circ} \mathrm{C}$, especially on the acidic $\mathrm{pH}$.

Effect of metal ions on lipase activity. The enzyme was incubated with various inorganic salts, metal chelators at $37^{\circ} \mathrm{C}$ for $30 \mathrm{~min}, \mathrm{pH}$ 7.0 , and the remaining activities of the incubation mixtures were assayed.

The results are presented in Table IV.

Table IV. Effect of Metal Ions on the ACTIVITY OF Chromobacterium LIPASE

One $\mathrm{ml}$ of enzyme was mixed with $1 \mathrm{ml}$ of $2 \times$ $10^{-3} \mathrm{M}$ test solution at $\mathrm{pH} 7.0$. After incubation at $37^{\circ} \mathrm{C}$ for $30 \mathrm{~min}$, the activity of the incubation mixture was assayed by the standard method.

\begin{tabular}{cc} 
Chemicals $^{a+}$ & Activity $(\%)$ \\
\hline $\mathrm{None}^{\prime}$ & 100 \\
$\mathrm{Cu}^{2+}$ & 35 \\
$\mathrm{Hg}^{2+}$ & 31 \\
$\mathrm{Na}^{+}$ & 108 \\
$\mathrm{Mn}^{2+}$ & 122 \\
$\mathrm{Li}^{+}$ & 114 \\
$\mathrm{Ni}^{2+}$ & 89 \\
$\mathrm{Ca}^{2+}$ & 144 \\
$\mathrm{~K}^{+}$ & 120 \\
$\mathrm{Mg}^{2+}$ & 144 \\
$\mathrm{~Pb}^{2+}$ & 91 \\
$\mathrm{Sn}^{2+}$ & 56 \\
$\mathrm{Co}^{2+}$ & 86 \\
$\mathrm{Ba}^{2+}$ & 100 \\
$\mathrm{Fe}^{3+}$ & 82 \\
$\mathrm{Al}^{3+}$ & 108 \\
$\mathrm{EDTA}^{2+}$ & 97 \\
\hline
\end{tabular}

a) Chloride-salts were used.

Among the tested compounds, $\mathrm{Cu}^{2+}, \mathrm{Hg}^{2+}$ and $\mathrm{Sn}^{2+}$ inactivate the enzyme, but $\mathrm{Ca}^{2+}$ $\mathrm{Mg}^{2+}$ and $\mathrm{Mn}^{2+}$ activate it.

Action of lipase on natural lipids and on a fatty acid esters. The data in Table V show the hydrolyzing ability of Chromobacterium lipase on a wide variety of lipid substrates.

The enzyme hydrolyzed various natural lipids although the extent differed each other. The enzyme rather showed preference of animal fats to vegetable ones.

Table VI shows the hydrolyzing ability of
Table V. Hydrolysis of Various Natural LIPIDS BY Chromobacterium LIPASE

The reaction mixture, composed of $1 \mathrm{~g}$ of lipid, $8 \mathrm{ml}$ of $0.1 \mathrm{M}$ phosphate buffer ( $\mathrm{pH} 7.0$ ) and $5.0 \mathrm{mg}$ of the crude lipase in $1 \mathrm{ml}$ of distilled water, was shaken in L-shape tube at $37^{\circ} \mathrm{C}$ for $7 \mathrm{hr}$.

Termination of the reaction and titration of the mixture were carried out in the same way as in lipase assay.

\begin{tabular}{lc}
\hline \multicolumn{1}{c}{ Lipid } & $\begin{array}{c}\text { Relative activity } \\
\text { (maximum }=100)\end{array}$ \\
\hline Lard & 91 \\
Butter & 86 \\
Fish oil & 82 \\
Olive oil & 64 \\
Soybean oil & 100 \\
Peanut oil & 59 \\
Cotton seed oil & 59 \\
Sesame oil & 55 \\
Rape oil & 64 \\
\hline
\end{tabular}

Table VI. Hydrolysis of Various Fatty ACID ESTERS BY Chromobacterium LIPASE

The experimental conditions were the same as those of the assay method of lipase except these substrates were used instead of olive oil.

\begin{tabular}{lc}
\hline \multicolumn{1}{c}{ Substrate } & $\begin{array}{c}\text { Relative activity } \\
\text { (Olive oil }=100 \text { ) }\end{array}$ \\
\hline Triacetin & 147 \\
Tripropionin & 129 \\
Tributyrin & 262 \\
Triolein & 100 \\
Tween 20 & 0 \\
Tween 40 & 9 \\
Tween 80 & 15 \\
Span 80 & 17 \\
Methyl- $n$-butyrate & 0 \\
Butyl- $n$-oleate & 31 \\
Amyl- $n$-acetate & 0
\end{tabular}

the enzyme on synthetic triglycerides and fatty acid esters.

The enzyme had hydrolytic activity on many kinds of fatty acid esters including water soluble ones. However, the lipase was more active on triglyceride than on solvitan ester, especially on tributyrin.

Effect of bile-salts on lipase activity. The enzyme was incubated with various concentrations of bile-salts at $37^{\circ} \mathrm{C}$ for $30 \mathrm{~min}, \mathrm{pH} 7.0$, 
and the activities of the incubation mixture were assayed.

As shown in Fig. 6, the activity of lipase was not diminished but rather stimulated by a high concentration of bile-salts.

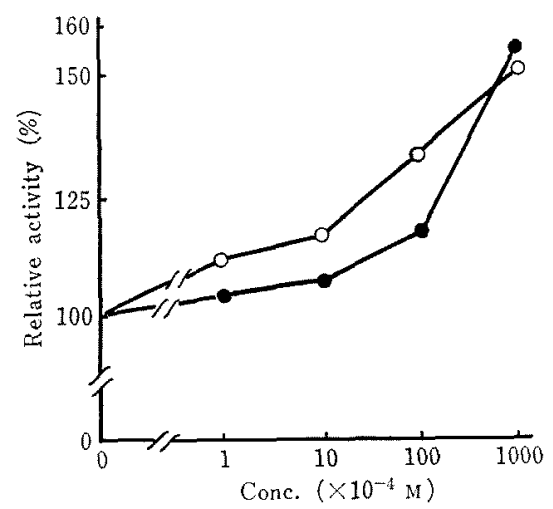

FIG. 6. Effect of Bile-salts on the Activity of Chromobacterium Lipase.

$\mathrm{O}-\mathrm{O}$; Na-taurocholate, Na-cholate.

One $\mathrm{ml}$ of enzyme was mixed with $1 \mathrm{ml}$ of bile-salt solutions ( $\mathrm{pH} 7.0)$ to give a final concentration as indicated. After incubation at $37^{\circ} \mathrm{C}$ for $30 \mathrm{~min}$, the activity of the incubation mixture was assayed by the standard method.

Pancreatic lipase is also stimulated by taurocholate or cholate.

Further studies on the characterization of the enzyme will be reported in the near future.

Acknowledgement. The authors wish to express their thanks to Drs. J. Abe and T. Watanabe of this laboratory for the discussion throughout this work.

\section{REFERENCES}

1) J. Fukumoto, M. Iwai and T. Tsujisaka, J. Gen. Appl. Microbiol., 9, 353 (1963).

2) S. Tatsuoka, A. Miyake, S. Wada, I. Imada, and C. Matsumura, J. Biochem., 46, 575 (1969).

3) J. Fukumoto, M. Iwai and T. Tsujisaka, J. Gen. Appl. Microbiol., 10, 257 (1964).

4) A. M. Stern, Z. J. Ordal and H. O. Halvorson, J. Bact., 68, 24 (1954).

5) K. Nagaoka, Y. Yamada and Y. Koaze, Agr. Biol. Chem., 33, 299 (1969).

6) K. Yamada and H. Machida, Nippon Nogeikagaku Kaishi, 36, 858 (1962).

7) N. Tomizuka, Y. Ota and K. Yamada, Agr. Biol. Chem., 30, 576 (1966).

8) Y. Ota and K. Yamada, ibid., 30, 351 (1966).

9) Y. Satomura, S. Oi and A. Sawada, Bull. Agr. Chem. Soc. Japan, 22, 194 (1958).

10) R. C. Lawrence, T. F. Fryer and B. Reiter, $J$. Gen. Microbiol., 48, 401 (1967).

11) D. B. Shah and J. B. Wilson, J. Bact., 89, 949 (1965).

12) K. Yamada, Y. Ota and H. Machida, Nippon Nogeikagaku Kaishi, 36, 860 (1962).

13) S. T. Cowan and K. J. Steel, "Manual for the Identification of Medical Bacteria," Cambridge University Press, 1965.

14) R. S. Breed, E. G. D. Murray and N. R. Smith, "Bergey's Manual of Determinative Bacteriology," 7 th ed., The William and Wilkins Co., Baltimore, 1961.

15) P. H. A. Sneath, J. Gen. Microbiol., 15, 70 (1956).

16) P. Desnulle, "Advances in Enzymology," Vol. 23, ed. by F. F. Nord, Interscience Publishers, Inc., 1961, p. 129.

17) R. C. Chandan and K. M. Shahani, J. Dairly Sci., 46, 503 (1963).

18) D. V. Vadehra and L. G. Harmon, Appl. Microbiol., 15, 480 (1967). 